\title{
EARLY PRECAMBRIAN GEOLOGY OF THE GODTHÅB AREA
}

\section{V.R. McGregor}

Work on the chronology of plutonic events in the Godthåb area, West Greenland, was continued in 1968. Geological mapping on a scale of 1:20000 was extended to the islands south of the town of Godthåb and to the peninsula west and south of Kobbefjorden. In addition, short excursions were made to the islands between Godthåb and Færingehavn, to the southern part of the Nordland peninsula and to the inner parts of Godthaibsfjord.

The new mapping has confirmed that the Ameralik dykes, a very dense swarm of metamorphosed, deformed and in many places migmatized basic dykes (McGregor, 1968), can be used to distinguish an old pre-Ameralik dyke basement from a post-Ameralik dyke cover of supracrustal amphibolites and metasedimentary gneisses and from granitic rocks, most of them deformed and recrystallized to gneisses, that intrude both cover and basement. Several large Ameralik dykes packed with inclusions of anorthosite have been found and it now appears that all or most of the "relic feldspar phenocrysts" that are found in many of the dykes are actually small anorthosite xenoliths.

Most of the pre-Ameralik dyke rocks are gneisses that appear to have been derived from homogeneous granitic (s.1.) rocks. At a few localities this derivation is very clear. In many places the gneisses have been strongly deformed before the intrusion of the Ameralik dykes. A very characteristic association of green-and-black skarn ultramafic rocks, various banded quartz ironstones, hornblendite, amphibolite and dark gneiss forms rafts in the gneisses. These are the only rocks found in the pre-Ameralik dyke basement to date for which a supracrustal origin might be invoked.

The informal name Malene supracrustals is introduced here for the sequence of supracrustal rocks, younger than the Ameralik dykes, that crops out in the area around Godthåb and is well exposed on the western slopes of the mountain Store Malene, east of Godthåb. The Malene supracrustals include pelitic and semipelitic gneisses, impure metaquartzites, gneisses rich in magnesian amphiboles, and several different types of 
amphibolite, one of which has well preserved pillow structures at a locality on Bjørneøen in Godthåbsfjord.

In the area east of Store Malene the Malene supracrustals crop out as continuous, thin units interlayered with pre-Ameralik dyke basement and pale homogeneous gneisses derived from granitic sills. It appears that one or more wedges of basement were thrust from the east into the supracrustal sequence. Small bodies of ultrabasic rocks are especially common along or close to the basement-supracrustal contacts and may have been emplaced along the thrust planes. The pile of basement and supracrustal slices was subsequently intruded by the granitic sills. The numerous thin granitic dykes that cut the basement rocks and the Ameralik dykes in some areas, and which previously were thought to have been older than the supracrustals, may be the same age as the large sills. The sequence of deformations that followed is still not fully understood. The present structure is dominated by moderately open folds with axes striking north-east to northnorth-east. At several localities these refold tight recumbent folds whose axes were parallel to those of the later folds.

West of Store Malene there is a complex of gneisses of intrusive origin, some of which contain many rafts and inclusions of amphibolite derived from the Malene supracrustals. A strip of intensely migmatized basement with Ameralik dykes is enclosed in the complex. Very similar gneisses of intrusive origin, also containing remnants of amphibolites of supracrustal type, crop out to the west on the other side of Godthabsfjord and form the southern part of the Nordland peninsula. The metamorphic grade here is granulite facies, whereas the metamorphic grade east of Godthåbsfjord is medium to high amphibolite facies. To the writer the field evidence strongly suggests that the Nordland and Godthåb complexes have similar histories and that the granulite facies metamorphism is younger than the Malene supracrustals and the Ameralik dykes. The writer could find no evidence that would support Windley's (1968) conclusion that the Godthåbsfjord area is a reworked "straight belt" significantly younger than the areas on either side of it.

The stratiform anorthosites of the Godthabsfjord area were found to be younger than the Ameralik dykes and to form sheets within the Malene supracrustals. Unlike the stratiform anorthosites of the Fiskenæsset area 
$130 \mathrm{~km}$ to the south (Ghisler and Windley, 1967), the Godthåbsfjord anorthosites are not genetically associated with significant quantities of basic or ultrabasic rocks. Nevertheless, it seems quite possible that the anorthosites of the two areas are of the same age, and that the chronologies of the two areas are broadly similar except that the plutonic activity about $2600 \mathrm{~m}$. y. ago, during which the Qorqut granite in the central part of the Godthåbsfjord area is now thought to have been generated, was much weaker in the Fiskenæsset area. Two dates older than $3000 \mathrm{~m}$. y. have been obtained from the Fiskenæsset area: a Re/Os date on molybdenite of $3080 \pm 70 \mathrm{~m}$.y. (Herr et al., 1967) and a K/Ar date on hornblende of $3210 \pm 80 \mathrm{~m}$. y. (R. StJ.Lambert and J.G.Simons, this report). In the light of these dates it seems quite possible that the Malene supracrustals, the Ameralik dykes and the preAmeralik dyke basement will prove to be older than $3100 \mathrm{~m} . \mathrm{y}$.

References

Ghisler, M. and Windley, B. F. (1967) The chromite deposits of the Fiskenæsset region, West Greenland. Rapp. Grфnlands geol. Unders., Nr. 12.

Herr, W., Wolfe, R., Eberhardt, P. and Kopp, E. (1967) Development and recent applications of the Re/Os dating method. In Radioactive dating and methods of low-level counting. Internat. Atomic Energy Agency, Vienna, 499-508.

McGregor, V.R. (1968) Field evidence of very old Precambrian rocks in the Godthåb area, West Greenland. Rapp. Grønlands geol. Unders., Nr. 15, $31-35$.

Windley, B.F. (1968) New field relations from the early Precambrian of West Greenland. Rapp. Gr $\phi$ nlands geol. Unders., Nr. 15, 27-31. 